\title{
GM-CSF Receptor
}

National Cancer Institute

\section{Source}

National Cancer Institute. GM-CSFReceptor. NCI Thesaurus. Code C38991.

Heterodimeric human GM-CSF Receptor is composed of Colony Stimulating Factor 2

Receptor Alpha Chain and Colony Stimulating Factor 2 Receptor Beta Chain. CSF2RA is a type I membrane protein with a box 1 motif for JAK interaction/activation and a WSXWS motif for protein folding, intracellular transport, and cell-surface receptor binding. The receptor signal transducing beta chain is common to the high affinity IL3-, IL5- and GMCSF receptors. CSF2R transduces the CSF2 signal for proliferation, differentiation, and activation of (primarily) granulocyte and macrophage hematopoietic cells. ( $\mathrm{NCl})$ 